\title{
Reduction of doxorubicin-induced genotoxicity by Handroanthus impetiginosus in mouse bone marrow revealed by micronucleus assay
}

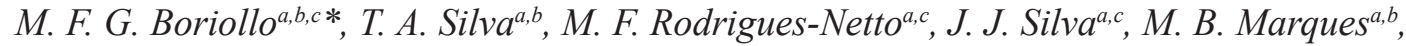 \\ C. T. S. Dias ${ }^{d}$, J. F. Höfling ${ }^{c}$, M. C. C. Resck ${ }^{a, b}$ and N. M. S. Oliveira ${ }^{a, b, e}$
}

áLaboratório de Farmacogenética e Biologia Molecular, Faculdade de Ciências Médicas, Universidade José do Rosário Vellano - UNIFENAS, Câmpus Universitário, Rod. MG 179, Km 0, CEP 37130-000, Alfenas, MG, Brazil

bÁrea de Patologia e Farmacologia Animal, Centro de Pesquisa e Pós-graduação em Ciência Animal, Universidade José do Rosário Vellano - UNIFENAS, Câmpus Universitário, Rod. MG 179, Km 0, CEP 37130-000, Alfenas, MG, Brazil

'Laboratório de Genética Molecular, Departamento de Diagnóstico Oral, Faculdade de Odontologia de Piracicaba - FOP, Universidade Estadual de Campinas - UNICAMP, Av. Limeira, 901, Areião, CEP 13414-903, Piracicaba, SP, Brazil

'Departamento de Ciências Exatas, Escola de Agricultura “Luiz de Queiroz" - ESALQ, Universidade de São Paulo - USP, Av. Pádua Dias, 11, CEP 13418-900, Piracicaba, SP, Brazil

'Laboratório de Ecotoxicologia e Microbiologia Ambiental, Faculdade de Tecnologia, Universidade Estadual de Campinas - UNICAMP, Rua Pedro Zaccaria, 1300, CEP 13484-350, Limeira, SP, Brazil

*e-mail: marcelo.boriollo@unifenas.br

Received: November 6, 2015 - Accepted: September 20, 2016 - Distributed: February 28, 2018

(With 1 figure)

\begin{abstract}
Handroanthus impetiginosus has long been used in traditional medicine and various studies have determined the presence of bioactive chemical compounds and potential phytotherapeutics. In this study, the genotoxicity of the lyophilized tincture of $H$. impetiginosus bark (THI) was evaluated in mouse bone marrow using micronucleus assays. The interaction between THI and genotoxic effects induced by the chemotherapeutic agent, doxorubicin (DXR), was also analyzed. Experimental groups were evaluated 24 to $48 \mathrm{~h}$ after treatment with N-nitroso-N-ethylurea (NEU; $50 \mathrm{mg} / \mathrm{kg})$, DXR $(5 \mathrm{mg} / \mathrm{kg})$, sodium chloride $(\mathrm{NaCl} ; 150 \mathrm{mM})$, and THI $(0.5-2 \mathrm{~g} / \mathrm{kg})$. Antigenotoxic assays were carried out using THI $(0.5 \mathrm{~g} / \mathrm{kg})$ in combination with NEU or DXR. Analysis of the micronucleated polychromatic erythrocytes (MNPCEs) indicated no significant differences between treatment doses of THI $(0.5-2 \mathrm{~g} / \mathrm{kg})$ and NaCl. Polychromatic erythrocyte (PCE) to normochromatic erythrocyte (NCE) ratios did not indicate any statistical differences between DXR and THI or $\mathrm{NaCl}$, but there were differences between THI and $\mathrm{NaCl}$. A significant reduction in MNPCEs and PCE/NCE ratios was observed when THI was administered in combination with DXR. This study suggested the absence of THI genotoxicity that was dose-, time-, and gender-independent and the presence of moderate systemic toxicity that was dose-independent, but time- and gender-dependent. The combination of THI and DXR also suggested antigenotoxic effects, indicating that THI reduced genotoxic effects induced by chemotherapeutic agents.
\end{abstract}

Keywords: Handroanthus impetiginosus (Mart. ex DC.) Mattos, phytotherapics, doxorubicin (DXR), micronucleus assay, bone marrow.

\section{Redução da genotoxicidade induzida pela doxorrubicina por Handroanthus impetiginosus na medula óssea de camundongos revelada pelo ensaio do micronúcleo}

\begin{abstract}
Resumo
Handroanthus impetiginosus tem sido usada durante um longo período pela medicina tradicional e vários estudos têm demonstrados a presença de compostos químicos e potencial fitoterapêutico. Esta pesquisa avaliou a genotoxicidade da tintura da casca liofilizada de H. impetiginosus (THI) usando o ensaio do micronúcleo em medula óssea de camundongos. A interação entre THI e os efeitos genotóxicos induzidos pelo quimioterápico doxorrubicina (DXR) também foram analisados. Grupos experimentais foram analisados a 24-48 h após o tratamento com N-Nitroso-N-etiluréia (NEU; $50 \mathrm{mg} / \mathrm{kg})$, DXR $(5 \mathrm{mg} / \mathrm{kg}), \mathrm{NaCl}(150 \mathrm{mM})$ e THI $(0,5-2 \mathrm{~g} / \mathrm{kg})$. O ensaio antigenotóxico foi conduzido utilizando THI $(0,5 \mathrm{~g} / \mathrm{kg})$ em combinação com NEU ou DXR. A análise de eritrócitos policromáticos micronucleados (EPCMNs) não mostrou diferenças significativas entre as doses de tratamento $(0,5-2 \mathrm{~g} / \mathrm{kg})$ e NaCl. As proporções de eritrócitos policromáticos (EPC)/eritrócitos normocromáticos (ENC) não revelaram diferenças estatísticas entre DXR e THI ou $\mathrm{NaCl}$, porém houve diferenças entre THI e $\mathrm{NaCl}$. Uma redução significativa em EPCMNs e na razão EPC/ENC foi
\end{abstract}


observada quando THI foi administrado em combinação com DXR. Essa pesquisa sugere ausência de genotoxicidade de THI, dose-, tempo- e sexo-independente, e moderada toxicidade sistêmica dose-independente, mas tempo- e sexo-dependente. A associação do THI e DXR também sugere efeitos antigenotóxicos. Por conseguinte, THI pode reduzir os efeitos genotóxicos induzidos pelo quimioterapêutico.

Palavras-chave: Handroanthus impetiginosus (Mart. ex DC.) Mattos, fitoterápico, doxorrubicina (DXR), ensaio do micronúcleo, medula óssea.

\section{Introduction}

Handroanthus impetiginosus (Mart. ex DC.) Mattos (synonyms: Gelseminum avellanedae (Lorentz ex Griseb.) Kuntze, Handroanthus avellanedae (Lorentz ex Griseb.) Mattos, Tabebuia avellanedae Lorentz ex Griseb., Tabebuia dugandii Standl., Tabebuia impetiginosa (Mart. ex DC.) Standl., Tabebuia nicaraguenses S.F.Blake, Tabebuia palmeri Rose, Tabebuia schunkevigoi D.R. Simpson, Tecoma adenophylla Bureau \& K. Schum., Tecoma avellanedae (Lorentz ex Griseb.) Speg., Tecoma integra (Sprague) Hassl.; family: Bignoniaceae) is a tree found in tropical forests in northeast Brazil. Historically, its purple bark ("Taheebo") was used as a medicine by millenarian tribes (Callawaya). Among its ethnopharmacological applications, the $H$. impetiginosus bark was used externally as a poultice or orally as a concentrated tea for the treatment of cancer, inflammatory disease, and fungal infection (De Santana et al., 1968; Hashimoto, 1996; Woo and Choi, 2005).

Over the past two decades, several studies have evaluated H. impetiginosus for the presence of phytochemical compounds and determined their phytotherapeutic potential as antiangiogenic agents (Kung et al., 2007), antimicrobial agents (methicillin-resistant Staphylococcus aureus) (Pereira et al., 2006), antinociceptive and antiedematogenic agents (De Miranda et al., 2001; Lee et al., 2012), antioxidants (Suo et al., 2013), wound healing agents (Kung et al., 2008), and antineoplastic agents (Kung et al., 2014). In addition, H. impetiginosus has been evaluated for use against colon carcinogenesis experimentally induced by azoxymethane in mice (Higa et al., 2011), DMBA (7,12-Dimethylbenz[a]anthracene)-induced carcinomas in $\mathrm{CBA} / \mathrm{Ca}$ inbred $\mathrm{H}-2 \mathrm{~K}$ haplotype mice (Budán et al., 2011), in human leukemia cells (U937, K562, HL60, and THP-1) (Moon et al., 2010), in human hepatocarcinoma cells (HepG2 and Hep3B) (Kim et al., 2007), in human bladder carcinoma T24 cells (Lee et al., 2006), in human prostate carcinoma DU145 cells (Lee et al., 2005), and others phytotherapeutic effects (Silva et al., 2003; Gómez Castellanos et al., 2009).

Plant extracts have also been screened for new pharmacological and herbal compounds capable of protecting normal cells against cumulative radiotherapeutic and chemotherapeutic toxicity (Canellos et al., 1975; Casciato and Scott, 1979; Hospers et al., 1999; Ferguson and Pearson, 1996). In this context, recent studies indicated protective effects of extracts from Aegle marmelos (Venkatesh et al., 2007), Copaifera langsdorffii (Alves et al., 2013), Helianthus annuus (Boriollo et al., 2014a), and Ziziphus joazeiro (Boriollo et al., 2014b) against chemotherapeutic DXR-induced cumulative toxicity (antigenotoxic effects).

In phytochemical studies involving $H$. impetiginosus, naphthoquinones, furanonaphthoquinones, anthraquinones, benzoic acid derivatives, benzaldehyde derivatives, iridoids, coumarins, flavonoids, and phenylpropanoid glycosides were isolated and identified (Ueda et al., 1994; Kreher et al., 1988; Pereira et al., 2006; Kim et al., 2007; Awale et al., 2005; Suo et al., 2013). Among the various quinones reported in the literature, lapachol and $\beta$-lapachone are of clinical importance because they have been associated with a variety of pharmacological activities (Oswald, 1993-1994; Silva et al., 2003; Gómez Castellanos et al., 2009). In addition, the biological activity of the quinones has been associated with the ability of the quinone moiety to generate stimuli for intracellular free radical production and reactive oxygen species (ROS) formation in mitochondrial and microsomal fractions (Dubin et al., 1990; Fry and Pudney, 1992; Henry and Wallace, 1995; Gómez Castellanos et al., 2009).

Although numerous studies have supported the effectiveness of different forms of the crude extract of H. impetiginosus or its phytochemical compounds alone, few recent studies aimed to understand their genotoxic and mutagenic effects (Vanni et al., 1998; De Sousa et al., 2009; Lemos et al., 2012; Zabka et al., 2013). To contribute to information about the genotoxic potential of herbal and natural products, the present study evaluated the genotoxic effects (clastogenicity and aneugenicity) of the lyophilized tincture of $H$. impetiginosus bark in the bone marrow of mice using a micronucleus assay. The action of this tincture on genotoxic effects induced by the chemotherapeutic agent, DXR, was also studied (antigenotoxic evaluation).

\section{Materials and Methods}

\subsection{Phytotherapeutic}

Tincture of H. impetiginosus (Mart. ex DC.) Mattos (THI) bark was purchased commercially and stored according to the manufacturer's recommendations (Yod Comércio de Produtos Naturais Ltda., cat. \# 280005, Campinas, SP, Brazil). Aliquots (1.5 L) of this extract were submitted to solvent removal proceedings by rotary evaporation (40 rpm) (Rotary Evaporator RV 10 Control V, IKA ${ }^{\circledR}$ Works, Inc., USA) coupled in bath heating systems $\left(40^{\circ} \mathrm{C}\right)$ (Heating Baths HB10, IKA ${ }^{\circledR}$ Works, Inc., USA), vacuum pump (175 mbar) (Chemistry diaphragm pump MD 1C, VACUUBRAND $\mathrm{GMBH}+\mathrm{CO}$ KG, Wertheim, Germany), recirculator of distilled water $\left(10^{\circ} \mathrm{C}\right)$ (Banho Ultratermostatizado Microprocessado Digital, SPLABOR, cod. \# SP-152/10, 
Presidente Prudente, SP, Brazil) and evaporation bottle (RV 10.85 Evaporation Flask, NS 29/32-2L, IKA ${ }^{\circledR}$ Works, Inc., USA). The final product was transferred to a reaction bottle $1 \mathrm{~L}$ (SCHOTT ${ }^{\circledR}$ DURAN $^{\circledR}$ ) and kept at $-20{ }^{\circ} \mathrm{C}$ for 24 hours in order to evaluate the freezing of the final product and the efficacy of the solvent evaporation process (Boriollo et al., 2014a, b). Then, aliquots $(40 \mathrm{ml})$ of this final product was transferred into glass vials penicillin type $(50 \mathrm{ml})$ and lyophilized $\left(0.12 \mathrm{mbar}\right.$ at $\left.-50{ }^{\circ} \mathrm{C}\right)$ (Lyophilizer model Alpha 1-2 LDPlus, Martin Christ Gefrier trocknung sanlagen $\mathrm{GmbH}^{\odot}$, Germany) and their dry mass were measured (Electronic Analytical Balance AUW-220D, Shimadzu Corp., Kyoto, Japan). The lyophilized final product was prepared in aqueous solvent (water type 1, Sistema Milli-Q Direct 8, Millipore Indústria e Comércio Ltda., Barueri, SP, Brazil) at concentrations of $2 \times$, sterilized by filtration (Millipore Corporation, hydrophilic Durapore ${ }^{\circledR}$ PVDF, $0.22 \mu \mathrm{m}, \varnothing 47 \mathrm{~mm}$, cat. \# GVWP 047 00), and stored in sterile polypropylene tubes $(50 \mathrm{ml})$ at $-70{ }^{\circ} \mathrm{C}$ until moment of use.

\subsection{System - test in vivo}

Healthy, heterogeneous, young adult male and female Swiss albinus (Unib: SW) mice (between 7 and 12 weeks - pubescent period), with a body weight between $30 \mathrm{~g}$ and $40 \mathrm{~g}$ (i.e., the variation weight between the animals, for each sex, should not exceed the $\pm 20 \%$ of medium mass) were provided by CEMIB (Centro Multidisciplinar para Investigação Biológica na Área da Ciência em Animais de Laboratório - UNICAMP; http://www.cemib. unicamp.br), and erythrocytes from the bone marrow of these mice were used in the micronucleus assay (OECD, 1997; Boriollo et al., 2014a, b). The animals were kept in groups of the same sex, in polypropylene boxes, in an air-conditioned environment to $22^{\circ} \mathrm{C} \pm 3{ }^{\circ} \mathrm{C}$, with relative air humidity of $50 \% \pm 20 \%$, and with 12 -hour day-night cycles (i.e., $12 \mathrm{~h}$ light and $12 \mathrm{~h}$ dark). These were fed with Purina ${ }^{\circledR}$ Labina commercial rations (Nestlé Purina Pet Care Company) and water ad libitum, and acclimated to laboratory conditions for 7 days (a trial period) before the execution of the experiment. At the end of the trial period, each animal was weighed and, according to the weight, received $2 \mathrm{ml} / 100 \mathrm{~g}$ body weight of the indicated liquid (negative control, positive control, chemotherapeutic and phytotherapeutic). After the experimental treatment, the animals were euthanized by $\mathrm{CO}_{2}$ asphyxiation in adapted acrylic chambers (Boriollo et al., 2014a, b). This research was approved by Committee of Ethics in Research Involving Animals of UNIFENAS (CEPEAU Protocol No. 08A/2014).

\subsection{Experimental groups}

Groups of animals (consisting of 3 males and 3 females each) were treated using a single dosing regimen administered by gavage (phytotherapeutic and negative control) or intraperitoneally (chemotherapeutic and positive control) and two euthanasia times ( 24 and $48 \mathrm{~h}$ ), based on a regulatory recommendation regarding the in vivo micronucleus assay (OECD, 1997; Boriollo et al., 2014a, b):
- Control groups: $150 \mathrm{mM} \mathrm{NaCl}$ (negative control), $50 \mathrm{mg} / \mathrm{kg}$ of N-Nitroso-N-ethylurea (positive control: NEU, Sigma N8509, CAS no. 759-73-9) and $5 \mathrm{mg} / \mathrm{kg}$ of doxorubicin hydrochloride (Boriollo et al., 2014a, b) (chemotherapeutic: DXR, Eurofarma Laboratórios Ltda., CAS no. 23214-92-8).

- Genotoxicity test (phytotherapeutics): 500, 1,000, 1,500 and $2,000 \mathrm{mg} / \mathrm{kg}$ of THI lyophilized and diluted in water type 1 . The maximum tolerated dose (MTD) was defined as ( $i$ ) the highest dose that can be administered without inducing lethality or excessive toxicity during the study causing moribund euthanasia, or (ii) a dose that produces some indication of toxicity of the bone marrow (e.g. a reduction in the proportion of immature erythrocytes among total erythrocytes in the bone marrow), or (iii) 2,000 mg/kg (OECD, 1997).

- Antigenotoxicity test (phytotherapeutics + chemotherapeutic) (Boriollo et al., 2014a, b): THI $(500 \mathrm{mg} / \mathrm{kg})+$ DXR $(5 \mathrm{mg} / \mathrm{kg})$ and THI $(500 \mathrm{mg} / \mathrm{kg})$ $+\operatorname{NEU}(5 \mathrm{mg} / \mathrm{kg})$.

\subsection{Processing the bone marrow and cell analysis}

Shortly after euthanasia, the femora were surgically and aseptically removed, and the animals appropriately discarded. Each femur was sectioned at the proximal end and the contents of the spinal canal were washed with $1.5 \mathrm{ml}$ of $150 \mathrm{mM} \mathrm{NaCl}$ solution and transferred to a $15 \mathrm{ml}$ centrifuge tube (OECD, 1997; Boriollo et al., $2014 a, b)$. This material was resuspended with a Pasteur pipette to ensure a random distribution of bone marrow cells. The suspension was then centrifuged at 1,000 rpm (Centrifuga de Bancada Microprocessada, Mod. NT 810, Nova Técnica Ind. e Com. de Equip. para Laboratório Ltda., Piracicaba, SP, Brazil) for 5 minutes. The supernatant was discarded and the resulting sediment was resuspended in $500 \mu \mathrm{L}$ of $150 \mathrm{mM} \mathrm{NaCI}$ solution added $4 \%$ formaldehyde. The slides were prepared by smearing ( 2 slides per animal), dried at room temperature for $24 \mathrm{~h}$ and stained with Leishman's eosin methylene blue dye [pure dye for $3 \mathrm{~min}$, followed by diluted dye in water type 1 (1:6) for $15 \mathrm{~min}$ ] to differentiate polychromatic erythrocyte (PCE) from normochromatic erythrocyte (NCE).

Polychromatic erythrocytes (PCEs) were observed at a magnification of $1,000 \times$ using optical microscopy (Nikon Eclipse E-200), counted (at least 2,000 polychromatic erythrocytes anucleated per animal were scored for the incidence of micronucleated polychromatic erythrocytes) with the aid of a digital cell counter (Contador Diferencial CCS02, Kacil Indústria e Comércio Ltda., PE, Brazil) and photographed using an 8.1 Megapixel Digital Camera (DC FWL 150). The number of PCEs and NCEs, the number and frequency of micronucleated polychromatic erythrocytes (MNPCEs) were reported. In order to evaluate bone-marrow toxicity, the ratio of polychromatic erythrocytes (PCE) to normochromatic erythrocytes (NCE) was also observed (OECD, 1997; Boriollo et al., 2014a, b). This PCE/NCE ratio is an indicator of the acceleration or 
inhibition of erythropoiesis and it has been reported to vary with scoring time. A continuous decline in the PCE/NCE ratio may be due to the inhibition of cell division, the killing of erythroblasts, the removal of damaged cells, or dilution of the existing cell pool with newly formed cells (OECD, 1997; Boriollo et al., 2014a, b).

\subsection{Statistical analysis}

The data obtained in the micronucleus assay were submitted to one-way analysis of variance (ANOVA), using a factorial scheme of $9 \times 2 \times 2$ (treatment $\times$ sex $\times$ euthanasia time), and medium comparison with Tukey's test $(\alpha=0.05)$ using $\mathrm{SAS}^{\circledR}$ version 9.3 computer software.

\section{Results and Discussion}

In the present study, the numbers and frequencies of MNPCEs and the PCE/NCE ratio in the bone marrow of mice were analyzed statistically for each of the animal groups treated with THI-genotoxic assay $(0.5,1.0$, 1.5 , and $2 \mathrm{~g} / \mathrm{kg}$ of THI) - and for each of the groups treated with THI and a chemotherapeutic agent, DXR or NEU_antigenotoxic assay $(0.5 \mathrm{~g} / \mathrm{kg}$ of THI $+5 \mathrm{mg} / \mathrm{kg}$ of DXR; $0.5 \mathrm{~g} / \mathrm{kg}$ of THI $+50 \mathrm{mg} / \mathrm{kg}$ of NEU) — as well as for the control groups. For animal groups treated with THI, analysis of the MNPCEs ( $n$ and \%) exhibited no significant differences $(p<0.05)$ between all the treatment doses [average values (\%) of $0.46 \pm 0.28(24 \mathrm{~h})$ and $0.29 \pm 0.13(48 \mathrm{~h})$ for $500 \mathrm{mg} / \mathrm{kg} ; 0.55 \pm 0.17(24 \mathrm{~h})$ and $0.49 \pm 0.13(48 \mathrm{~h})$ for $1,000 \mathrm{mg} / \mathrm{kg} ; 0.66 \pm 0.37(24 \mathrm{~h})$ and $0.70 \pm 0.15(48 \mathrm{~h})$ for $1,500 \mathrm{mg} / \mathrm{kg}$; and $0.80 \pm 0.21$ $(24 \mathrm{~h})$ and $0.81 \pm 0.23(48 \mathrm{~h})$ for $2,000 \mathrm{mg} / \mathrm{kg}]$ and negative control $(\mathrm{NaCl})$ [average values $(\%)$ of $0.44 \pm 0.1(24 \mathrm{~h})$ and $0.50 \pm 0.08$ (48 h)] (Table 1; Table 1S in Supplementary material). These results suggested that THI was not genotoxic, regardless of the dose administered (Figure 1A), the gender of the animal (male or female) (Figure 1B), or the treatment time $(24$ or $48 \mathrm{~h}$ ) (Figure 1C). Mice treated with $5 \mathrm{mg} / \mathrm{kg}$ of DXR significantly $(p<0.05)$ induced MNPCE 24 and $48 \mathrm{~h}$ after treatment in both genders [average values (\%) $2.68 \pm 0.42(24 \mathrm{~h})$ and $2.66 \pm 0.43$ (48 h)]. The MNPCE frequencies in the DXR group were significantly $(p<0.05)$ higher than those observed in the positive NEU control group $(50 \mathrm{mg} / \mathrm{kg}$ ) [average values (\%) $2.30 \pm 1.62(24 \mathrm{~h})$ and $1.74 \pm 0.19$ (48 h)] (Figure 1A). However, a significant reduction in MNPCE $(p<0.05)$ was observed when THI $(500 \mathrm{mg} / \mathrm{kg})$ was administered in combination with the chemotherapeutic agent DXR $(5 \mathrm{mg} / \mathrm{kg})$, suggesting antigenotoxic effects (anticlastogenicity and antianeugenicity) [average values (\%) $0.55 \pm 0.06(24 \mathrm{~h})$ and $0.70 \pm 0.25$ (48 h)] (Figure 1A). Therefore, THI provided protection against the genotoxic effects induced by DXR in the bone marrow of mice, regardless of the treatment time ( 24 or $48 \mathrm{~h}$ ) or the gender of the animal. Similarly, the combination of THI $(500 \mathrm{mg} / \mathrm{kg})$ and NEU $(5 \mathrm{mg} / \mathrm{kg})$ indicated a partial protection against the genotoxic effects induced by positive control in the micronucleus assay (anticlastogenicity and antianeugenicity effects) [average values $(\%) 1.07 \pm 0.26(24 \mathrm{~h})$ and $1.02 \pm 0.36(48 \mathrm{~h})]$ (Table 1, Table 1S in Supplementary material and Figure 1).

The analysis of the PCE/NCE ratio indicated no significant differences $(p<0.05)$ between the chemotherapeutic agent DXR [average values $0.92 \pm 0.07(24 \mathrm{~h})$ and $0.97 \pm 0.01(48 \mathrm{~h})$ ] and all doses of THI [average values $0.81 \pm 0.12(24 \mathrm{~h})$ and $0.88 \pm 0.07(48 \mathrm{~h})$ for $500 \mathrm{mg} / \mathrm{kg}$, $0.83 \pm 0.10(24 \mathrm{~h})$ and $0.89 \pm 0.06(48 \mathrm{~h})$ for $1,000 \mathrm{mg} / \mathrm{kg}$, $0.81 \pm 0.10(24 \mathrm{~h})$ and $0.89 \pm 0.05(48 \mathrm{~h})$ for $1,500 \mathrm{mg} / \mathrm{kg}$, and $0.87 \pm 0.07(24 \mathrm{~h})$ and $0.88 \pm 0.10(48 \mathrm{~h})$ for $2,000 \mathrm{mg} / \mathrm{kg}$ ] or negative control $(\mathrm{NaCl})$ [average value $0.99 \pm 0.005$ (24-48 h)]. There were significant differences between all doses of THI and negative control $(\mathrm{NaCl})$. In addition, there were significant differences between positive NEU control $(50 \mathrm{mg} / \mathrm{kg})$ [average values $0.53 \pm 0.09(24 \mathrm{~h})$ and $0.66 \pm 0.19(48 \mathrm{~h})]$ and all other treatments (Table 1, Table 1S in Supplementary material, and Figure 1D). Taken together, these results suggested that there was gender-(Figure 1E) and time-dependent (Figure 1F) moderate systemic toxicity of THI under the MN assay conditions, regardless of the phytotherapeutic dose. Interestingly, the PCE/NCE ratio observed after treatment with THI $(500 \mathrm{mg} / \mathrm{kg})$ and DXR $(5 \mathrm{mg} / \mathrm{kg})$ [average values $0.98 \pm 0.03(24 \mathrm{~h})$ and $0.98 \pm 0.01(48 \mathrm{~h})]$ or THI $(500 \mathrm{mg} / \mathrm{kg})$ and NEU $(50 \mathrm{mg} / \mathrm{kg})$ [average values $0.98 \pm 0.01(24 \mathrm{~h})$ and $0.98 \pm 0.02(48 \mathrm{~h})$ ] in antigenotoxic assays showed no significant differences $(p<0.05)$ compared with that with negative control (Figure 1D). These results suggested that THI combined with the chemotherapeutic agent, DXR, reduced or cancelled any toxic effect induced by THI or DXR. In addition, THI provided gender- and time-dependent protection against toxic effects induced by NEU in the bone marrow of mice (Figures 1E and 1F). The evaluation of the potentially antigenotoxic effects (chemotherapeutic + phytotherapeutic) associated with the absence of systemic toxicity of THI could be determined from dosages $<500 \mathrm{mg} / \mathrm{kg}$, or from the identification, purification, and exploitation of the phytochemical compounds in THI.

The acute toxicity and antiedematogenic and antinociceptive effects of an aqueous extract of $H$. impetiginosus inner bark were previously studied in various animal models (Swiss mice and Wistar rats, male and female) (De Miranda et al., 2001). In that study, H. impetiginosus presented antinociceptive and antiedematogenic activities, in which the antinociceptive effect was associated with the adenosine system. The mortality index was observed over $48 \mathrm{~h}$ and there was no $\mathrm{LD}_{50}$ when mice received the aqueous extract at concentrations of 1,3 , and $5 \mathrm{~g} / \mathrm{kg}$ (p.o.). However, the authors indicated that the plant had a low toxicity profile (De Miranda et al., 2001). The genotoxic potential of $H$. impetiginosus bark and stem and its association with the reference mutagen DXR (antigenotoxic effects) were evaluated using a wing spot test in Drosophila melanogaster (Somatic Mutation and Recombination Test - SMART) using the standard (ST) version to evaluate direct action and the high bioactivation (HB) version to evaluate indirect action (De Sousa et al., 2009). The bark and stem of $H$. impetiginosus were toxic at a higher concentration $(40 \% \mathrm{w} / \mathrm{w})$, but did not induce 


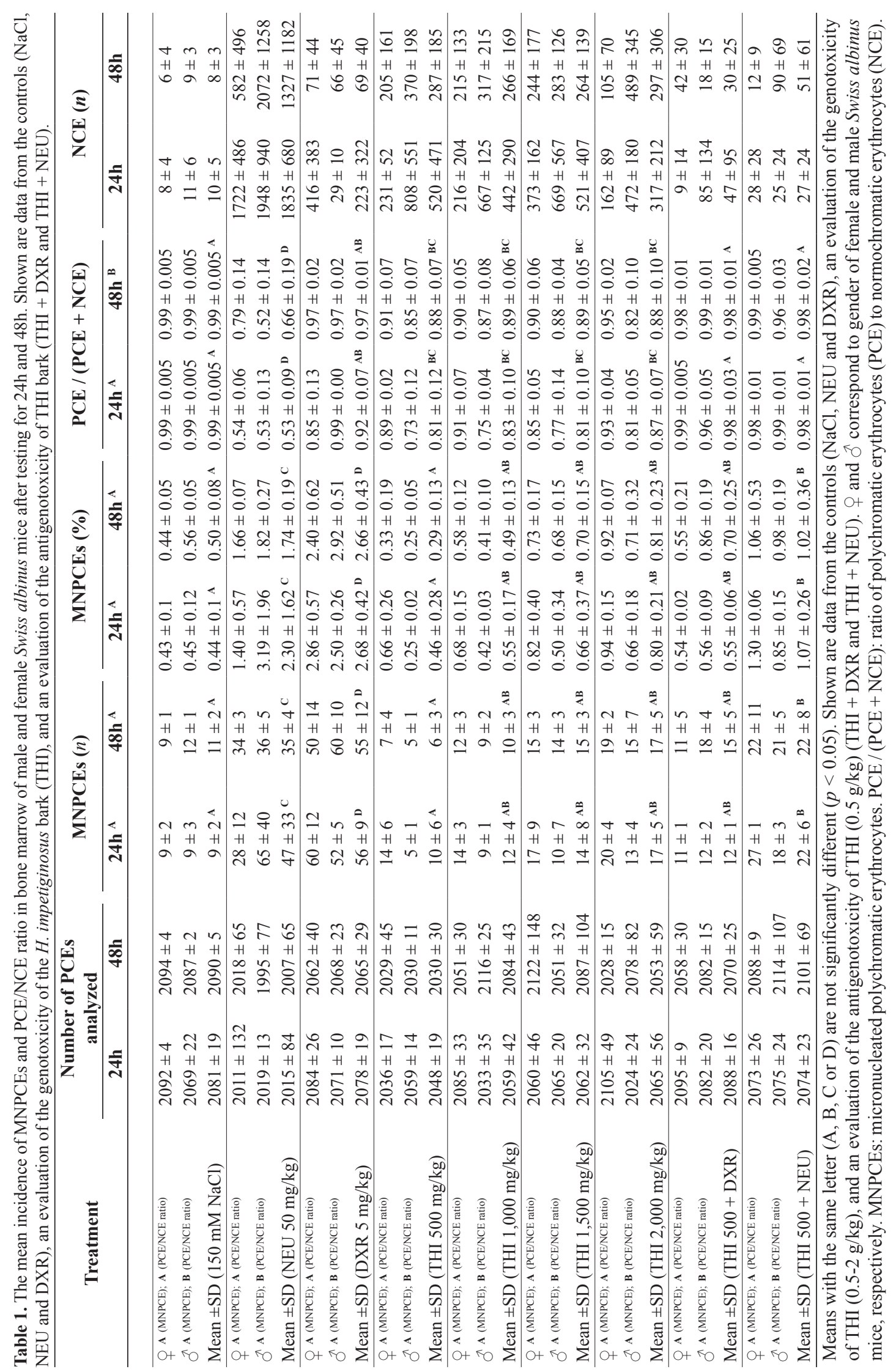


somatic mutation and recombination in D. melanogaster from ST and HB crossbreeding. That is, H. impetiginosus alone neither acted as a genotoxin nor exerted any antigenotoxic effects on spontaneous DNA lesions. However, H. impetiginosus displayed a considerable potentiating effect on DXR genotoxicity $(0.125 \mathrm{mg} / \mathrm{ml})$ that was inversely proportional to the concentration applied $(10 \%, 20 \%$, and $40 \% \mathrm{w} / \mathrm{w})$, indicating a dose-response relationship with toxicity (De Sousa et al., 2009). In other studies, the genotoxic activities of the hydroalcoholic extract of $H$. impetiginosus inflorescences were assessed using a comet assay [Single Cell-Gel Electrophoresis (SCGE)]
A. Distribution of freq. (\%) MNPCEs

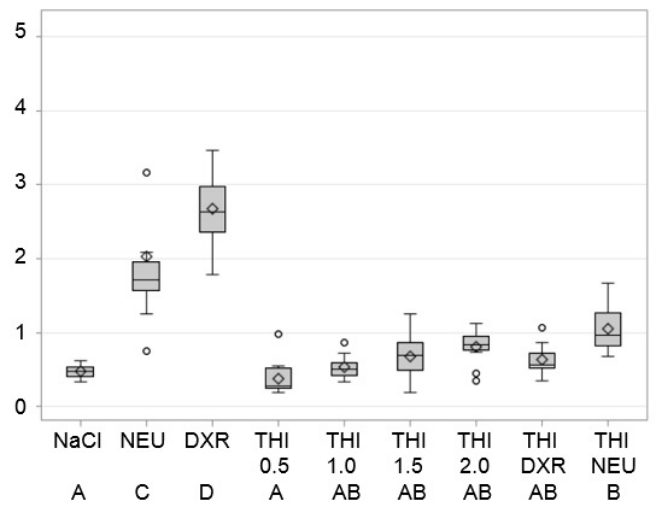

B. Distribution of freq. (\%) MNPCEs

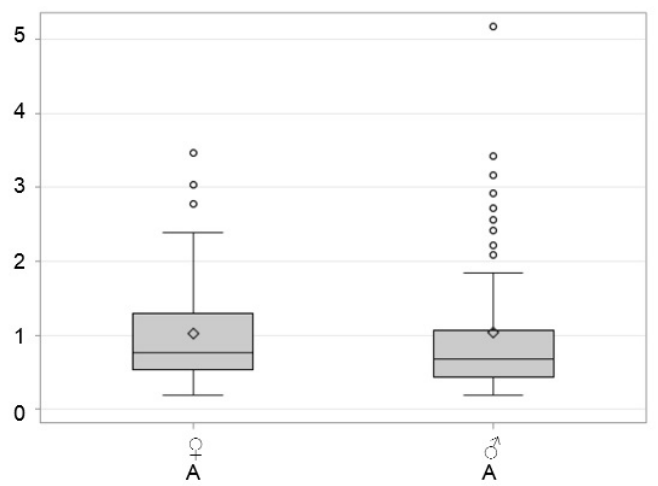

C. Distribution of freq. (\%) MNPCEs

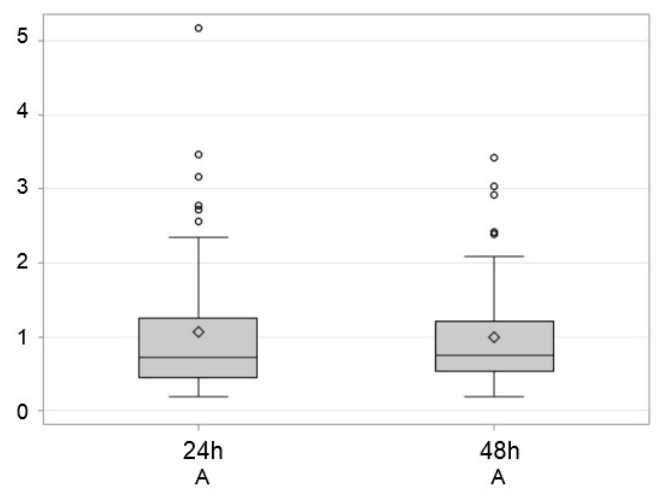

D. Distribution of $P C E /$

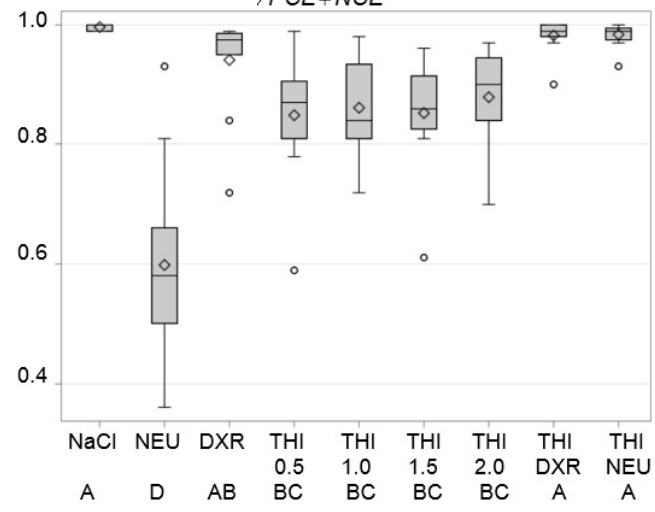

E. Distribution of $P C E /$

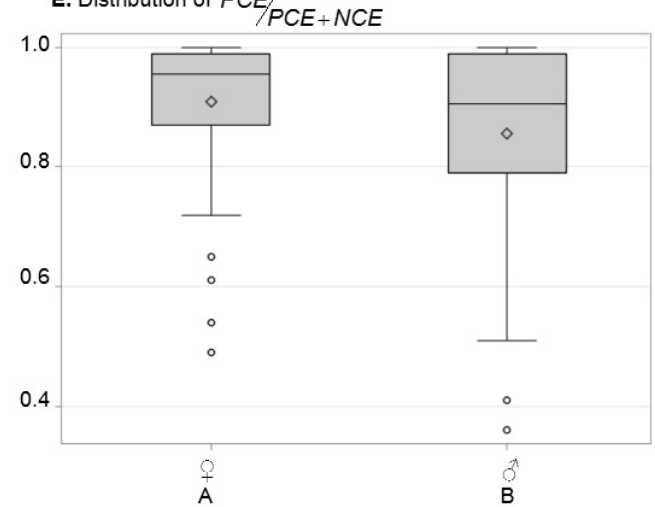

F. Distribution of $P C E / P C E+N C E$

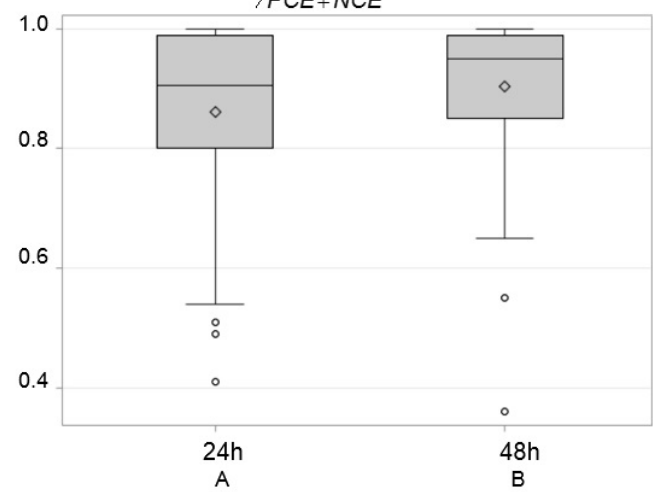

Figure 1. Box-plots showing the incidence of micronucleated polychromatic erythrocytes (MNPCEs) and ratio of polychromatic erythrocytes (PCE) to normochromatic erythrocytes (NCE) in bone marrow of male ( $\left.\jmath^{\Uparrow}\right)$ and female ( $(+)$ Swiss albinus mice after testing for $24 \mathrm{~h}$ and $48 \mathrm{~h}$. Shown are data from the controls $(150 \mathrm{mM} \mathrm{NaCl}, \mathrm{NEU} 50 \mathrm{mg} / \mathrm{kg}$ and DXR $5 \mathrm{mg} / \mathrm{kg}$ ), an evaluation of the genotoxicity of the H. impetiginosus bark (THI: $0.5-2 \mathrm{~g} / \mathrm{kg}$ ), and an evaluation of the antigenotoxicity of THI bark (THI $0.5 \mathrm{~g} / \mathrm{kg}+$ DXR $5 \mathrm{mg} / \mathrm{kg}$; THI $0.5 \mathrm{~g} / \mathrm{kg}+$ NEU $50 \mathrm{mg} / \mathrm{kg}$ ). Means with the same letter (A, B, C or D) are not significantly different $(p<0.05)$. 
in order to detect the extent of DNA damage in blood and liver cells from male Wistar rats (Lemos et al., 2012). The analysis of liver and blood cells after $24 \mathrm{~h}$ of treatment (100,300, and $500 \mathrm{mg} / \mathrm{kg}$ of body weight) revealed extensive DNA damage when compared to negative control (drinking-water), with the exception of the treatment at $100 \mathrm{mg} / \mathrm{kg}$ when considering only blood cells. These data suggested a dose-dependent genotoxicity of H. impetiginosus inflorescence in Wistar rats and, therefore, inferences about its use in alternative medicine requires caution (Lemos et al., 2012).

Among the phytochemical compounds identified in $H$. impetiginosus, lapachol and $\beta$-lapachone stand out for their pharmacological activity (Silva et al., 2003; Gómez Castellanos et al., 2009). Characterization of the genotoxic mechanisms of $\beta$-lapachone (commercial source) was performed in cultured Chinese hamster ovary ( $\mathrm{CHO}$ ) cells (Vanni et al., 1998). In that study, $\beta$-lapachone was cytotoxic (on $\mathrm{S}$ phase cells) and genotoxic (induced DNA strand breaks) in logarithmically growing $\mathrm{CHO}$ cells at concentrations around $10 \mu \mathrm{M}$. $\beta$-lapachone inhibited the activity of poly (ADP-ribose) polymerase (PARP) and increased the activity of topoisomerase I. In addition, these data taken together suggested that $\beta$-lapachone did not directly damage DNA. It is possible that the strong genotoxic potential observed in this study reflected the interference of $\beta$-lapachone with the delicate DNA metabolizing machinery, in which both PARP and topoisomerase I play a central role (Vanni et al., 1998). However, it is also possible that $\beta$-lapachone induced a small number of DNA strand breaks owing to its ability to produce activated oxygen species (Docampo et al., 1979; Molina Portela and Stoppani, 1996; Molina Portela et al., 1996).

$\beta$-lapachone (3,4-dihydro-2,2-dimethyl-2H-naphthol[1,2-b] pyran-5,6-dione, ARQ 501), a natural $o$-naphthoquinone and a major component in an ethanol extract of $H$. impetiginosus bark, displayed promising antitumor activity in various tumor cells (Pardee et al., 2002; Tagliarino et al., 2003; Terai et al., 2009; Tan et al., 2012) and has been tested as an antitumor drug in phase I, II, and III clinical trials in combination with other chemotherapeutic agents (Pardee et al., 2002; Bentle et al., 2007). The anticancer activity of $\beta$-lapachone may involve its catalysis by $\mathrm{NAD}(\mathrm{P})$ H:quinone oxidoreductase (NQO1, DT-diaphorase), which used NAD(P)H or NADH as an electron source to yield the two-electron reduction of $\beta$-lapachone (Pardee et al., 2002; Reinicke et al., 2005). In the presence of NQO1, $\beta$-lapachone underwent reduction to an unstable hydroquinone, resulting in the generation of ROS, including superoxides (Pink et al., 2000; De Witte et al., 2004; Choi et al., 2007). In turn, these reactive oxygen species oxidized thiol groups of the mitochondrial potential transition pore complex, leading to increased inner membrane permeability, reduced membrane depolarization, release of cytochrome c, and cell death (Lemasters et al., 1998; Smaili et al., 2000). The expression of NQO1 in solid cancers is higher than in normal tissues (Belinsky and Jaiswal., 1993), including in carcinoma of the liver (Schlager and Powis, 1990), colon (Smitskamp-Wilms et al., 1995), breast (Schlager and Powis, 1990; Smitskamp-Wilms et al., 1995), brain (Berger et al., 1985), and lung (Schlager and Powis, 1990). In addition, NQO1 has been shown to be an important factor in $\beta$-lapachone-induced cell death in many kinds of cancer cells (Pink et al., 2000; Reinicke et al., 2005), including breast cancer (Tagliarino et al., 2003), glioma (Park et al., 2011), and prostate cancer (Pink et al., 2000). In this context, other methods have been examined to increase NQO1 expression or activity in cancer cells (Terai et al., 2009; Tan et al., 2012; Satsu et al., 2012) in order to increase the clinical efficacy of $\beta$-lapachone. More recently, the genotoxic impact and genotoxic activities of the combination of $\beta$-lapachone and hydroxyurea (another anticancer drug and an inhibitor of ribonucleotide reductase) were reported in Allium cepa root meristem cells (Zabka et al., 2013). Treatment with $\beta$-lapachone $(100 \mathrm{mM})$ and hydroxyurea $(0.75 \mathrm{mM})$ generated hydrogen peroxide $\left(\mathrm{H}_{2} \mathrm{O}_{2}\right)$ and induced DNA double strand breaks, which was correlated with $\gamma$-phosphorylation of H2AX histones by using an immunoassay. However, the extent of H2AX phosphorylation was considerably reduced in root meristem cells treated jointly with $\beta$-lapachone and hydroxyurea. In addition, treatment with $\beta$-lapachone $(100 \mathrm{mM})$ alone resulted in a lower number of M-phase cells, an increase in the occurrence of mitotic abnormalities (over-condensation and enhanced stickiness of chromosomes, formation of anaphase bridges, and micronucleation), a reduction in mitotic spindles, and induction of apoptosis-like programmed cell death. In turn, hydroxyurea treatment alone led to adaptation of cells to replication stress and promotion of abnormal nuclear divisions with biphasic interphase/mitotic states of chromatin condensation (Zabka et al., 2013).

The presence of multiple molecules in plants may be advantageous because some may counteract the toxicity of others, and as a result, the net effect may be beneficial for therapeutic purposes. For example, the effect of various concentrations of $A$. marmelos (Venkatesh et al., 2007), C. langsdorffii (Alves et al., 2013), H. annuus (Boriollo et al., 2014a), and Z. joazeiro (Boriollo et al., 2014b) on doxorubicin (DXR)-induced genotoxic effects in mice bone marrow was studied. The treatment of mice with A. marmelos, for consecutive days before DXR treatment, significantly reduced the frequency of DXR-induced micronuclei and increased the PCE/NCE ratio at all scoring times compared with DXR treatment alone. This chemoprotective effect may be assigned to the sum total of interactions between different ingredients of this complex mixture. However, the degree of protection may depend on the interaction of components individually or collectively with the genotoxic agent. The plausible mechanisms of action of $A$. marmelos in protecting against DXR-induced genomic insult were scavenging of $\mathrm{O}_{2}^{-}$and $\cdot \mathrm{OH}$ and other free radicals, increase in antioxidant status, restoration of topoisomerase II activity, and inhibition of the formation of DXR-iron complex (Venkatesh et al., 2007). The results of other studies demonstrated that 
C. langsdorffii was not itself genotoxic and that, in animals treated with the combination of $C$. langsdorffii Desf. and $\mathrm{DXR}$, the number of micronuclei significantly decreased compared to animals receiving DXR alone, according to the Swiss mouse peripheral blood micronucleus test. The putative antioxidant activity of one or more of the active compounds of $C$. langsdorffii, including two major flavonoid heterosides (quercitrin and afzelin) may explain the effect of this plant on DXR-induced genotoxicity (Alves et al., 2013). More recently, the absence of genotoxicity of the tincture and two sources of oils of $H$. annuus was observed in the bone marrow of Swiss albinus mice using micronucleus assay, but indications of antigenotoxic effects were related to combination treatment with the tincture and DXR, suggesting a partial protective mechanism against DXR-induced genotoxic effects (Boriollo et al., 2014a). Finally, the nongenotoxicity of $Z$. joazeiro and its antigenotoxic effects when administered together with DXR were also related as shown by micronucleus assay in the bone marrow of Swiss albinus mice (Boriollo et al., 2014b).

In conclusion, this study reports information with an emphasis on mutagenesis, especially on the possible genotoxic and antigenotoxic effects of a lyophilized tincture of H. impetiginosus bark using in vivo micronucleus assay in mouse bone marrow, which has recently been the subject of little research. The results suggested the absence of genotoxicity (clastogenicity and aneugenicity) of $H$. impetiginosus [dose $(0.5-2 \mathrm{~g} / \mathrm{kg})$, time- $(24-48 \mathrm{~h})$, and gender-independent (male and female)]. Relatively little systemic toxicity (acute and chronic in bone marrow) was observed in the micronucleus test conditions by the proportion of PCE/NCE data. However, combination treatment with $H$. impetiginosus $(0.5 \mathrm{~g} / \mathrm{kg})$ and DXR $(5 \mathrm{mg} / \mathrm{kg}$ ) showed antigenotoxic effects (anticlastogenicity and antianeugenicity) and a significant reduction in toxicity, which suggested that the extract of $H$. impetiginosus bark provided protection against toxic and genotoxic effects induced by the chemotherapeutic agent, DXR, in the bone marrow of mice (time- and gender-independent antigenotoxic effect, time- and gender-dependent antitoxic effect).

More studies involving the evaluation of the genotoxicity of extracts and phytochemical compounds found in H. impetiginosus (Mart. ex DC.) Mattos should be conducted, including mutagenicity assays with Salmonella typhimurium test (Ames test) as an indicator of potential carcinogenicity to mammals, gene mutation test in mammalian cells (mouse lymphoma assay), cytogenetic and aneuploidy tests in vitro, micronucleus tests in cultured cells in vitro, fluorescent in situ hybridization (FISH) tests for mutagenesis, comet tests to detect DNA damage and repair in individual cells, and functional genomic and proteomic tests for mutagenesis (cDNA microarrays and other array analyses) to characterize their potential genotoxic and antigenotoxic effects and the molecular mechanisms involved. In addition, studies should be conducted to establish limits for human consumption, delineate potential risks to human health, and provide rational strategies for implementing chemo-preventive measures.

\section{Acknowledgements}

This research was supported by Rede Mineira de Ensaios Toxicológicos e Farmacológicos de Produtos Terapêuticos - REDE MINEIRA TOXIFAR, Fundação de Amparo à Pesquisa do Estado de Minas Gerais - FAPEMIG (RED 00008-14), Conselho Nacional de Desenvolvimento Cientifico e Tecnológico - $\mathrm{CNPq}$ and Coordenação de Aperfeiçoamento de Pessoal de Nivel Superior-CAPES.

\section{References}

ALVES, J.M., MUNARI, C.C., DE AZEVEDO BENTES MONTEIRO NETO, M., FURTADO, R.A., SENEDESE, J.M., BASTOS, J.K. and TAVARES, D.C., 2013. In vivo protective effect of Copaifera langsdorffii hydroalcoholic extract on micronuclei induction by doxorubicin. Journal of Applied Toxicology, vol. 33, no. 8, pp. 854-860. PMid:22611044. http://dx.doi.org/10.1002/jat.2777.

AWALE, S., KAWAKAMI, T., TEZUKA, Y., UEDA, J.Y., TANAKA, K. and KADOTA, S., 2005. Nitric oxide (NO) production inhibitory constituents of Tabebuia avellanedae from Brazil. Chemical \& Pharmaceutical Bulletin, vol. 53, no. 6, pp. 710-713. PMid:15930790. http://dx.doi.org/10.1248/cpb.53.710.

BELINSKY, M. and JAISWAL, A.K., 1993. NAD(P)H: quinone oxidoreductase1 (DTdiaphorase) expression in normal and tumor tissues. Cancer and Metastasis Reviews, vol. 12, no. 2, pp. 103117. PMid:8375015. http://dx.doi.org/10.1007/BF00689804.

BENTLE, M.S., REINICKE, K.E., DONG, Y., BEY, E.A. and BOOTHMAN, D.A., 2007. Nonhomologous end joiningis essential for cellular resistance to the novel antitumor agent, beta-lapachone. Cancer Research, vol. 67, no. 14, pp. 6936-6945. PMid:17638905. http://dx.doi.org/10.1158/0008-5472.CAN-07-0935.

BERGER, M.S., TALCOTT, R.E., ROSENBLUM, M.L., SILVA, M., ALIOSMAN, F. and SMITH, M.T., 1985. Use of quinones in brain-tumor therapy: preliminary results of preclinical laboratory investigations. Journal of Toxicology and Environmental Health, vol. 16, no. 5, pp. 713-719. PMid:2419579. http://dx.doi. org/10.1080/15287398509530781.

BORIOLLO, M.F.G., RESENDE, M.R., DA SILVA, T.A., PÚBLIO, J.Y., SOUZA, L.S., DIAS, C.T., DE MELLO SILVA OLIVEIRA, N. and FIORINI, J.E., 2014a. Evaluation of the mutagenicity and antimutagenicity of Ziziphus joazeiro Mart. bark in the micronucleus assay. Genetics and Molecular Biology, vol. 37, no. 2, pp. 428-438. PMid:25071409. http://dx.doi.org/10.1590/ S1415-47572014000300016.

BORIOLLO, M.F., SOUZA, L.S., RESENDE, M.R., SILVA, T.A., OLIVEIRA, N.M., RESCK, M.C., DIAS, C.T. and FIORINI, J.E., 2014b. Nongenotoxic effects and a reduction of the DXRinduced genotoxic effects of Helianthus annuus Linné (sunflower) seeds revealed by micronucleus assays in mouse bone marrow. BMC Complementary and Alternative Medicine, vol. 14, p. 121. PMid:24694203. http://dx.doi.org/10.1186/1472-6882-14-121.

BUDÁN, F., SZABÓ, I., VARJAS, T., NOWRASTEH, G., DÁVID, T., GERGELY, P., VARGA, Z., MOLNÁR, K., KÁDÁR, B., ORSÓS, Z., KISS, I. and EMBER, I., 2011. Mixtures of Uncaria and Tabebuia extracts are potentially chemopreventive in $\mathrm{CBA} / \mathrm{Ca}$ mice: a long-term experiment. Phytotherapy Research, vol. 25, no. 4, pp. 493-500. PMid:20799345. http://dx.doi.org/10.1002/ ptr.3281. 
CANELLOS, G.P., ARSENEAU, J.C., DEVITA, V.T., WHANGPENG, J. and JOHNSON, R.E., 1975. Second malignancies complicating Hodgkin's disease in remission. Lancet, vol. 1, no. 7913, pp. 947-949. PMid:48122. http://dx.doi.org/10.1016/ S0140-6736(75)92007-3.

CASCIATO, D.A. and SCOTT, J.L., 1979. Acute leukemia following prolonged cytotoxic agent therapy. Medicine, vol. 58, no. 1, pp. 32-47. PMid:105227. http://dx.doi.org/10.1097/00005792197901000-00002.

CHOI, E.K., TERAI, K., JI, I.M., KOOK, Y.H., PARK, K.H., OH, E.T., GRIFFIN, R.J., LIM, B.U., KIM, J.S., LEE, D.S., BOOTHMAN, D.A., LOREN, M., SONG, C.W. and PARK, H.J., 2007. Up regulation of $\mathrm{NAD}(\mathrm{P}) \mathrm{H}$ : quinine oxidoreductase by radiation potentiates the effect of bioreductive $\beta$-lapachone on cancer cells. Neoplasia (New York, N.Y.), vol. 9, no. 8, pp. 634-642. PMid:17786182. http://dx.doi.org/10.1593/neo.07397.

DE MIRANDA, F.G., VILAR, J.C., ALVES, I.A., CAVALCANTI, S.C. and ANTONIOLLI, A.R., 2001. Antinociceptive and antiedematogenic properties and acute toxicity of Tabebuia avellanedae Lor. ex Griseb. inner bark aqueous extract. $B M C$ Pharmacology, vol. 1, p. 6. PMid:11574048. http://dx.doi. org/10.1186/1471-2210-1-6.

DE SANTANA, C.F., DE LIMA, O., D’ ALBUQUERQUE, I.L., LACERDA, A.L. and MARTINS, D.G., 1968. Observações sobre as propriedades antitumorais e toxicológicas do extrato do líber e de alguns componentes do cerne do Pau d'arco (Tabebuia avellanedae). Revista do Instituto de Antibioticos, vol. 8, no. 1, pp. 89-94. PMid:5761014.

DE SOUSA, N.C., DE REZENDE, A.A., DA SILVA, R.M., GUTERRES, Z.R., GRAF, U., KERR, W.E. and SPANÓ, M.A., 2009. Modulatory effects of Tabebuia impetiginosa (Lamiales, Bignoniaceae) on doxorubicin-induced somatic mutation and recombination in Drosophila melanogaster. Genetics and Molecular Biology, vol. 32, no. 2, pp. 382-388. PMid:21637695. http:// dx.doi.org/10.1590/S1415-47572009005000042.

DE WITTE, N.V., STOPPANI, A.O. and DUBIN, M., 2004. 2-Phenyl-beta-lapachone can affect mitochondrial function by redox cycling mediated oxidation. Archives of Biochemistry and Biophysics, vol. 432, no. 2, pp. 129-135. PMid:15542051. http:// dx.doi.org/10.1016/j.abb.2004.09.020.

DOCAMPO, R., CRUZ, F.S., BOVERIS, A., MUNIZ, R.P. and ESQUIVEL, D.M., 1979. Esquivel, $\beta$-lapachone enhancement of lipid peroxidation and superoxide anion and hydrogen peroxide formation by sarcoma 180 ascites tumor cells. Biochemical Pharmacology, vol. 28, no. 6, pp. 723-728. PMd:222291. http:// dx.doi.org/10.1016/0006-2952(79)90348-4.

DUBIN, M., FERNANDEZ VILLAMIL, S.H. and STOPPANI, A.O., 1990. Inhibition of microsomal lipid peroxidation and cytochrome P-450-catalyzed reactions by $\beta$-lapachone and related naphthoquinones. Biochemical Pharmacology, vol. 39, no. 7, pp. 1151-1160. PMid:2157443. http://dx.doi.org/10.1016/00062952(90)90256-K.

FERGUSON, L.R. and PEARSON, A.E., 1996. The clinical use of mutagenic anticancer drugs. Mutation Research, vol. 355, no. 1-2, pp. 1-12. PMid:8781574. http://dx.doi.org/10.1016/00275107(96)00019-X.

FRY, M. and PUDNEY, M., 1992. Site of action of the antimalarial hydroxynaphtaquinone, 2-[trans-4-(4'-chlorophenyl) cyclohexyl]-3-hydroxy-1,4-naphthoquinone (566C80). Biochemical
Pharmacology, vol. 43, no. 7, pp. 1545-1553. PMid:1314606. http://dx.doi.org/10.1016/0006-2952(92)90213-3.

GÓMEZ CASTELLANOS, J.R., PRIETO, J.M. and HEINRICH, M., 2009. Red Lapacho (Tabebuia impetiginosa) - a global ethnopharmacological commodity? Journal of Ethnopharmacology, vol. 121, no. 1, pp. 1-13. PMid:18992801. http://dx.doi.org/10.1016/j. jep.2008.10.004.

HASHIMOTO, G., 1996. Illustrated cyclopedia of Brazilian medical plants. Kamakura: Aboc-sha. 158 p.

HENRY, T.R. and WALLACE, K.B., 1995. Differential mechanisms of induction of the mitochondrial permeability transition by quinines of varying chemical reactivities. Toxicology and Applied Pharmacology, vol. 134, no. 2, pp. 195-203. PMid:7570595. http://dx.doi.org/10.1006/taap.1995.1184.

HIGA, R.A., AYDOS, R.D., SILVA, I.S., RAMALHO, R.T. and SOUZA, A.S., 2011. Study of the antineoplastic action of Tabebuia avellanedae in carcinogenesis induced by azoxymethane in mice. Acta Cirurgica Brasileira, vol. 26, no. 2, pp. 125-128. PMid:21445475. http://dx.doi.org/10.1590/S0102-86502011000200009.

HOSPERS, G.A., EISENHAUER, E.A.E. and DE-VRIES, E.G., 1999. The sulfhydryl containing compounds WR-2721 and glutathione as radio - and chemoprotective agents: a review, indications for use and prospects. British Journal of Cancer, vol. 80, no. 5-6, pp. 629-638. PMid:10360638. http://dx.doi. org/10.1038/sj.bjc.6690404.

KIM, S.O., KWON, J.I., JEONG, Y.K., KIM, G.Y., KIM, N.D. and CHOI, Y.H., 2007. Induction of Egr-1 is associated with anti-metastatic and anti-invasive ability of $\beta$-lapachone in human hepatocarcinoma cells. Bioscience, Biotechnology, and Biochemistry, vol. 71, no. 9, pp. 2169-2176. PMid:17827686. http://dx.doi.org/10.1271/bbb.70103.

KREHER, B., LOTTER, H., CORDELL, G.A. and WAGNER, H., 1988. New furano naphthoquinones and other constituents of Tabebuia avellanedae and their immunomodulating activities in vitro. Planta Medica, vol. 54, no. 6, pp. 562-563. PMid:17265346. http://dx.doi.org/10.1055/s-2006-962561.

KUNG, H.N., CHIEN, C.L., CHAU, G.Y., DON, M.J., LU, K.S. and CHAU, Y.P., 2007. Involvement of NO/cGMP signaling in the apoptotic and anti-angiogenic effects of $\beta$-lapachone on endothelial cells in vitro. Journal of Cellular Physiology, vol. 211, no. 2, pp. 522-532. PMid:17192848. http://dx.doi.org/10.1002/jcp.20963.

KUNG, H.N., WENG, T.Y., LIU, Y.L., LU, K.S. and CHAU, Y.P., 2014. Sulindac compounds facilitate the cytotoxicity of $\beta$ lapachone by up-regulation of $\mathrm{NAD}(\mathrm{P}) \mathrm{H}$ quinone oxidoreductase in human lung cancer cells. PLoS One, vol. 9, no. 2, e88122. PMid:24505400. http://dx.doi.org/10.1371/journal.pone.0088122.

KUNG, H.N., YANG, M.J., CHANG, C.F., CHAU, Y.P. and LU, K.S., 2008. In vitro and in vivo wound healing-promoting activities of $\beta$-lapachone. American Journal of Physiology. Cell Physiology, vol. 295, no. 4, pp. C931-C943. PMid:18650264. http://dx.doi.org/10.1152/ajpcell.00266.2008.

LEE, J.H., CHEONG, J., PARK, Y.M. and CHOI, Y.H., 2005. Down-regulation of cyclooxigenase-2 and telomerase activity by $\beta$-lapachone in human prostate carcinoma cells. Pharmacological Research, vol. 51, no. 6, pp. 553-560. PMid:15829436. http:// dx.doi.org/10.1016/j.phrs.2005.02.004.

LEE, J.I., CHOI, D.Y., CHUNG, H.S., SEO, H.G., WOO, H.J., CHOI, B.T. and CHOI, Y.H., 2006. $\beta$-lapachone induces growth inhibition and apoptosis in bladder cancer cells by modulation of 
Bcl-2 family and activation of caspases. Experimental Oncology, vol. 28, no. 1, pp. 30-35. PMid:16614704.

LEE, M.H., CHOI, H.M., HAHM, D.H., HER, E., YANG, H.I., YOO, M.C. and KIM, K.S., 2012. Analgesic and anti-inflammatory effects in animal models of an ethanolic extract of Taheebo, the inner bark of Tabebuia avellanedae. Molecular Medicine Reports, vol. 6, no. 4, pp. 791-796. PMid:22825254.

LEMASTERS, J.J., NIEMINEN, A.L., QIAN, T., TROST, L.C., ELMORE, S.P., NISHIMURA, Y., CROWE, R.A., CASCIO, W.E., BRADHAM, C.A., BRENNER, D.A. and HERMAN, B., 1998. The mitochondrial permeability transition in cell death: a common mechanism in necrosis, apoptosis and autophagy. Biochimica et Biophysica Acta, vol. 1366, no. 1-2, pp. 177-196. PMid:9714796. http://dx.doi.org/10.1016/S0005-2728(98)00112-1.

LEMOS, O.A., SANCHES, J.C.M., SILVA, I.E.F., SILVA, M.L.A., VINHÓLIS, A.H.C., FELIX, M.A.P., SANTOS, R.A. and CECCHI, A.O., 2012. Genotoxic effects of Tabebuia impetiginosa (Mart. Ex DC.) Standl. (Lamiales, Bignoniaceae) extract in Wistar rats. Genetics and Molecular Biology, vol. 35, no. 2, pp. 498-502. PMid:22888300. http://dx.doi.org/10.1590/ S1415-47572012005000030.

MOLINA PORTELA, M.P. and STOPPANI, A.O., 1996a. Redox cycling of $\beta$-lapachone and related o-naphthoquinones in the presence of dihydrolipoamide and oxygen. Biochemical Pharmacology, vol. 51, no. 3, pp. 275-283. PMid:8573194. http:// dx.doi.org/10.1016/0006-2952(95)02168-X.

MOLINA PORTELA, M.P., FERNANDEZ VILLAMIL, S.H., PERISSINOTTI, L.J. and STOPPANI, A.O., 1996b. Redox cycling of o-naphthoquinones in trypanosomatids. Superoxide and hydrogen peroxide production. Biochemical Pharmacology, vol. 52, no. 12 , pp. 1875-1882. PMid:8951346. http://dx.doi. org/10.1016/S0006-2952(96)00601-6.

MOON, D.O., KANG, C.H., KIM, M.O., JEON, Y.J., LEE, J.D., CHOI, Y.H. and KIM, G.Y., 2010. $\beta$-lapachone (LAPA) decreases cell viability and telomerase activity in leukemia cells: suppression of telomerase activity by LAPA. Journal of Medicinal Food, vol. 13, no. 3, pp. 481-488. PMid:20438329. http://dx.doi. org/10.1089/jmf.2008.1219.

ORGANISATION FOR ECONOMIC COOPERATION AND DEVELOPMENT - OECD, 1997. OECD Guideline for the Testing of Chemicals: Mammalian erythrocyte micronucleus test. Paris: OECD. Guideline 474

OSWALD, E.H., 1993-1994. Review of Lapacho (pau d'arco). British Journal of Physiotherapy, vol. 3, pp. 112-117.

PARDEE, A.B., LI, Y.Z. and LI, C.J., 2002. Cancer therapy with $\beta$-lapachone. Current Cancer Drug Targets, vol. 2, no. 3, pp. 227242. PMid:12188909. http://dx.doi.org/10.2174/1568009023333854.

PARK, E.J., CHOI, K.S. and KWON, K.S., 2011. Beta-Lapachoneinduced reactive oxygen species (ROS) generation mediates autophagic cell death in glioma U87 MG cells. Chemico-Biological Interactions, vol. 189, no. 1-2, pp. 37-44. PMid:21035436. http:// dx.doi.org/10.1016/j.cbi.2010.10.013.

PEREIRA, E.M., MACHADO, T.B., LEAL, I.C., JESUS, D.M., DAMASO, C.R., PINTO, A.V., GIAMBIAGI-DEMARVAL, M., KUSTER, R.M. and SANTOS, K.R., 2006. Tabebuia avellanedae naphthoquinones: Activity against methicillin-resistant staphylococcal strains, cytotoxic activity and in vivo dermal irritability analysis. Annals of Clinical Microbiology and Antimicrobials, vol. 5, p. 5. PMid:16553949. http://dx.doi.org/10.1186/1476-0711-5-5.
PINK, J.J., PLANCHON, S.M., TAGLIARINO, C., VARNES, M.E., SIEGEL, D. and BOOTHMAN, D.A., 2000. NAD(P)H: Quinone oxidoreductase activity is the principal determinant of $\beta$-lapachone cytotoxicity. The Journal of Biological Chemistry, vol. 275, no. 8, pp. 5416-5424. PMid:10681517. http://dx.doi. org/10.1074/jbc.275.8.5416.

REINICKE, K.E., BEY, E.A., BENTLE, M.S., PINK, J.J., INGALLS, S.T., HOPPEL, C.L., MISICO, R.I., ARZAC, G.M., BURTON, G., BORNMANN, W.G., SUTTON, D., GAO, J. and BOOTHMAN, D.A., 2005. Development of beta-lapachone pro drugs for therapy against human cancer cells with elevated NAD(P) H: quinine oxidoreductase 1 levels. Clinical Cancer Research, vol. 11, no. 8, pp. 3055-3064. PMid:15837761. http://dx.doi. org/10.1158/1078-0432.CCR-04-2185.

SATSU, H., CHIDACHI, E., HIURA, Y., OGIWARA, H., GONDO, Y. and SHIMIZU, M., 2012. Induction of NAD(P)H: quinine oxidoreductase 1 expression by cysteine via Nrf2 activation in human intestinal epithelial LS180 cells. Amino Acids, vol. 43, no. 4, pp. 1547-1555. PMid:22302369. http://dx.doi.org/10.1007/ s00726-012-1230-1.

SCHLAGER, J.J. and POWIS, G., 1990. Cytosolic NAD(P)H: (quinone-acceptor) oxidoreductase in human normal and tumor tissue: effects of cigarette smoking and alcohol. International Journal of Cancer, vol. 45, no. 3, pp. 403-409. PMid:2307529. http://dx.doi.org/10.1002/ijc.2910450304.

SILVA, M.N., FERREIRA, V.F. and SOUZA, M.C.B.V., 2003. Um panorama atual da química e da farmacologia de naftoquinonas, com ênfase na beta-lapachona e derivados. Quimica Nova, vol. 26 , no. 3, pp. 407-416. http://dx.doi.org/10.1590/S010040422003000300019

SMAILI, S.S., HSU, Y.T., YOULE, R.J. and RUSSELL, J.T., 2000. Mitochondria in Ca2+ signaling and apoptosis. Journal of Bioenergetics and Biomembranes, vol. 32, no. 1, pp. 35-46. PMid:11768760. http://dx.doi.org/10.1023/A:1005508311495.

SMITSKAMP-WILMS, E., GIACCONE, G., PINEDO, H.M., VAN DER LAAN, B.F. and PETERS, G.J., 1995. DT-diaphorase activity in normal and neoplastic human tissues; an indicator for sensitivity tobio reductive agents? British Journal of Cancer, vol. 72, no. 4, pp. 917-921. PMid:7547240. http://dx.doi.org/10.1038/ bjc. 1995.433 .

SUO, M., OHTA, T., TAKANO, F. and JIN, S., 2013. Bioactive Phenylpropanoid Glycosides from Tabebuia avellanedae. Molecules (Basel, Switzerland), vol. 18, no. 7, pp. 7336-7345. PMid:23797703. http://dx.doi.org/10.3390/molecules18077336.

TAGLIARINO, C., PINK, J.J., REINICKE, K.E., SIMMERS, S.M., WUERZBERGER-DAVIS, S.M. and BOOTHMAN, D.A., 2003. Mu-calpain activation in beta-lapachone-mediated apoptosis. Cancer Biology \& Therapy, vol. 2, no. 2, pp. 141-152. PMid:12750552. http://dx.doi.org/10.4161/cbt.2.2.237.

TAN, X.L., MARQUARDT, G., MASSIMI, A.B., SHI, M., HAN, W. and SPIVACK, S.D., 2012. High through put library screening identifies two novel NQO1 inducers in human lung cells. American Journal of Respiratory Cell and Molecular Biology, vol. 46, no. 3, pp. 365-371. PMid:22021338. http:// dx.doi.org/10.1165/rcmb.2011-0301OC.

TERAI, K., DONG, G.Z., OH, E.T., PARK, M.T., GU, Y., SONG, C.W. and PARK, H.J., 2009. Cisplatin enhances the anticancer effect of beta-lapachone by up regulating NQO1. Anti-Cancer Drugs, vol. 20, no. 10, pp. 901-909. PMid:19738461. http:// dx.doi.org/10.1097/CAD.0b013e328330098d.

UEDA, S., UMEMURA, T., DOHGUCHI, K., MATSUZAKI, T., TOKUDA, H., NISHINO, H. and IWASHIMA, A., 1994. 
Production of anti-tumour-promoting furanonaphthoquinones in Tabebuia avellanedae cell cultures. Phytochemistry, vol. 36, no. 2, pp. 323-325. PMid:7764878. http://dx.doi.org/10.1016/ S0031-9422(00)97069-9.

VANNI, A., FIORE, M., DE SALVIA, R., CUNDARI, E., RICORDY, R., CECCARELLI, R. and DEGRASSI, F., 1998. DNA damage and cytotoxicity induced by $\beta$-lapachone: relation to poly (ADP-ribose) polymerase inhibition. Mutation Research, vol. 401, no. 1-2, pp. 55-63. PMid:9639674. http://dx.doi. org/10.1016/S0027-5107(97)00273-X.

VENKATESH, P., SHANTALA, B., JAGETIA, G.C., RAO, K.K. and BALIGA, M.S., 2007. Modulation of doxorubicin-Induced genotoxicity by Aegle marmelos in mouse bone marrow: A micronucleus study. Integrative Cancer Therapies, vol. 6, no. 1, pp. 42-53. PMid:17351026. http://dx.doi.org/10.1177/1534735406298302.

WOO, H.J. and CHOI, Y.H., 2005. Growth inhibition of A549 human lung carcinoma cells by $\beta$-lapachone through induction of apoptosis and inhibition of telomerase activity. International Journal of Oncology, vol. 26, no. 4, pp. 1017-1023. PMid:15753997.

ZABKA, A., TRZASKOMA, P. and MASZEWSKI, J., 2013. Dissimilar effects of $\beta$-lapachone- and hydroxyurea-induced DNA replication stress in root meristem cells of Allium cepa. Plant Physiology and Biochemistry, vol. 73, pp. 282-293. PMid:24184448. http://dx.doi.org/10.1016/j.plaphy.2013.10.001. 


\section{Supplementary Material}

Supplementary material accompanies this paper.

Table 1S. The incidence of MNPCEs and PCE/NCE ratio in bone marrow of male and female Swiss albinus mice after testing for $24 \mathrm{~h}$ and $48 \mathrm{~h}$. Shown are data from the controls ( $\mathrm{NaCl}, \mathrm{NEU}$ and DXR), an evaluation of the genotoxicity of the H. impetiginosus bark (THI), and an evaluation of the antigenotoxicity of THI bark (THI + DXR and THI + NEU).

This material is available as part of the online article from http://www.scielo.br/bjb. 